\title{
Demogeografski razvoj hrvatskog pograničja 2001. - 2011.
}

DOI: https://doi.org/10.11567/met.34.2.1 UDK: 314.04(497.5-04)“2001/2011“" 314.116-022.252(497.5-04)"2001/2011“" 314.1-043.92(497.5-04)“2001/2011“ Izvorni znanstveni rad Primljeno: 10.11.2018.

Prihvaćeno: 13.12.2018.

\section{Ivan Zupanc}

Geografski odsjek, Prirodoslovno-matematički fakultet, Sveučilište u Zagrebu, Zagreb izupanc@geog.pmf.hr

\section{SAŽETAK}

Rad se bavi demografskim procesima u hrvatskome pograničnom području tijekom posljednjega međupopisnog razdoblja 2001. - 2011. Pristup analizi je demogeografski, stoga je naglasak na prostornoj analizi demografskih podataka. Pogranično područje izdvojeno je na temelju jedinica lokalne samouprave (JLS), tj. općina i gradova koji dotiču granicu. Demogeografski pristup izdvojio je tri razine analize: pograničje u cjelini, općine/gradovi koji izlaze na granicu te pogranična naselja, unutar kojih su posebno razmatrana najuža pogranična naselja koja neposredno dotiču granicu. Ukupno kretanje stanovništva analizirano je na svim razinama, a kod pograničja u cjelini te JLS-a razmatrane su i komponente (prirodno i mehaničko kretanje). Analiza sastavnica pokazala je kako se ukupna depopulacija javlja pod dominantnim utjecajem iseljavanja, tj. negativnoga migracijskog salda. U pograničnom pojasu naselja depopulacija je također temeljni demografski proces koji je zahvatio 72,3\% naselja, a u najužem pojasu broj stanovnika smanjio se za $8,6 \%$, dok je depopuliralo $77,1 \%$ naselja. Dobna struktura ne pokazuje izrazitije znakove starenja pograničja u cjelini od ostalog dijela Hrvatske, no ipak se starenje intenziviralo, pa se u 115 JLS-a indeks starosti povećao, dok se koeficijent starosti povećao u 86 JLS-a. Glavni je uzrok smanjenje mladog stanovništva. Iako su se broj i udio samačkih kućanstava u pograničnom pojasu povećali, nešto su manji no uostalom dijelu Hrvatske. S druge strane, struktura samačkih kućanstava prema dobi pokazala je da gotovo dvije trećine samačkih kućanstava pograničja čine članovi u dobi 60 i više godina, što je iznad državnog prosjeka i dijela Hrvatske izvan pograničja.

KLJUČNE RIJEČI: pograničje, Hrvatska, demogeografija, stanovništvo, depopulacija, starenje 


\section{UVOD}

Zbog oblika, veličine i položaja teritorija Hrvatska ima izrazit granični karakter. Ukupna duljina vanjske kopnene granice državnog teritorija iznosi 2370,5 km. Kada bismo kopnenu površinu Hrvatske $(56.594$ km²) prikazali krugom, njegov bi opseg iznosio svega $843,3 \mathrm{~km}$. Usporedimo li krug koji bi imao opseg jednak duljini hrvatske kopnene granice, njegova bi površina iznosila $447.167,3 \mathrm{~km}^{2}$ (7,9 puta veća od kopnene površine $\left.\mathrm{RH}\right)$. Ako pak pribrojimo duljinu morske obale na kopnu $(1880 \mathrm{~km})$ hrvatskoj kopnenoj granici, dobit ćemo opseg od 4250,5 km. Krug takva opsega imao bi površinu čak $1.437 .706,3 \mathrm{~km}^{2}$ (25,4 puta veću od $\mathrm{RH}$ ). Najdulji dio vanjske granice prostire se prema Bosni i Hercegovini (1010,9 km ili 42,6\%), zatim Republici Sloveniji (659,1 km, 27,8\%), Mađarskoj (355,2 km, 15,0\%), Republici Srbiji (325,8 km, 13,7\%) te Crnoj Gori (19,5 km, 0,8\%) (Statistički ljetopis Republike Hrvatske, 2017). Pogranično područje Hrvatske zbog svoje duljine i različitih geografskih obilježja vrlo je heterogeno, što uvjetuje i dodatno strateško značenje tog dijela državnog teritorija. Zbog svega taj se prostor smatra područjem od posebnog interesa.

Hrvatska ima nekoliko kategorija problemskih područja, među kojima su i područja uz državnu granicu, odnosno pogranična područja. Ona se nerijetko preklapaju i s drugim kategorijama problemskih područja kao što su ratom zahvaćena područja, brdsko-planinska i ruralna, što problematiku njihova razvoja čini još složenijom. Stjecanjem samostalnosti većina hrvatskih perifernih (rubnih) područja postala je dodatno marginalizirana zbog uspostave novih državnih granica. Neka od obilježja takvih problemskih područja s ograničenjima u razvoju jesu i negativni demografski procesi, odnosno demografsko zaostajanje.

Uspostavom novih država Hrvatske i Slovenije najprije se javio pojačani interes za proučavanje problematike stanovništva pograničja između tih dviju država. Dio tih radova bavio se čitavim pograničjem Hrvatske (Kržišnik-Bukić, 1995, 1997b; Repolusk, 1995, 1999; Pokos, 1997; Josipovič i Kržišnik-Bukić, 2010), a dio izdvojenim sekcijama (Crkvenčić, 1998, 2001, 2002; Zupanc, 2001a, 2001b; Josipovič, 2007; Bognar i Bognar, 2010). Osim nove državne granice između Hrvatske i Slovenije, znatno manju pozornost privukla je pogranična zona prema Bosni i Hercegovini (Crkvenčić, 2004a, 2004b) i Mađarskoj (Crkvenčić i Crkvenčić, 2003a, 2003b). Tek nekoliko radova bavilo se čitavim hrvatskim pograničnim područjem (Nejašmić, 2005, 2008; Pokos i Mišetić, 2009; Nejašmić i Toskić, 2015). 
Iako se pojačani interes za proučavanjem pograničnog dijela Hrvatske javio odmah po osamostaljenju Hrvatske, valja istaknuti kako je popis 1991. proveden još za vrijeme bivše države (SFRJ) na temelju Zakona o provođenju popisa stanovništva, domaćinstava, stanova i poljoprivrednih gospodarstava u 1991. godini (Službeni list SFRJ, 3/90, 72/90; Narodne novine, 16/90, 47/90), ${ }^{1}$ zbog čega tek međupopisno razdoblje 2001. - 2011. (s izuzetkom granice prema Mađarskoj) predstavlja vremenski okvir s početnim i završnim stanjem u kojem se ono može smatrati stvarnim pograničnim područjem.

Demogeografski pristup $\mathrm{u}$ ovom radu upotrebljava tri razine prostorne analize demografskih podataka. Prvu razinu čini pogranično područje (pojas ili zona) koje obuhvaća 128 gradova i općina. Za komparativnu analizu upotrijebljeni su: a) dio Hrvatske koji je je izvan definiranog područja pograničja i b) Hrvatska u cjelini. Druga su razina jedinice lokalne samouprave (JLS), tj. općine i gradovi. To je središnji dio analize koji obuhvaća sastavnice općega (ukupnoga) kretanja stanovništva, tj. prirodno i mehaničko kretanje, kako bi se ustanovili uzroci, njihov međuodnos i intenzitet. Osim toga naglasak je na analizi najvažnije strukture stanovništva - dobnoj strukturi, tj. procesu starenja kao posljedici i pokazatelju depopulacije. Treća su razina naselja u pograničnim općinama/gradovima (ukupno 1877) za koje je provedena analiza općega kretanja stanovništva. Na toj razini posebno su promatrana i naselja iz najužega pograničnog pojasa koji čini 599 naselja koja neposredno dotiču granicu te se taj pojas može smatrati dodatnom razinom. To su ujedno i glavni ciljevi rada, čija je svrha rasvijetliti ključne demografske probleme pograničja Republike Hrvatske u suvremenom razdoblju 2001. - 2011.

\section{METODOLOŠKE NAPOMENE}

\subsection{Definicija pograničnog područja}

Iako je suvremeni administrativno-teritorijalni ustroj Hrvatske pogodniji za ovakve vrste definiranja pograničja od primjerice onoga koji je bio aktualan u vrijeme popisa 1991., još uvijek postoje različiti pristupi. Pogranično područje moguće je izdvojiti na više načina. Tako je Strategija prostornog uređenja $R H$ iz 1997. pogranični pojas definirala sa 128 tadašnjih gradova i općina koji participiraju u kopnenome graničnom području (neposredno

U trenutku popisa 1991. Hrvatska je bila podijeljena na 102 općine, od kojih je 45 izlazilo na granicu (državnu i/ili republičku). 
izlaze na granicu), dok je Program prostornog uređenja $R H$ iz 1999. definirao područja uz državnu granicu na kopnu kao »teritorij grada ili općine neposredno uz državnu granicu i ako je sjedište grada/općine udaljeno do $10 \mathrm{~km}$ od granice (Program prostornog uređenja RH, 1999: 76). ${ }^{2}$ Do sada je u literaturi koja se bavi čitavim hrvatskim pograničnim područjem primijenjen isti kriterij neposrednog izlaska na granicu (Pokos i Mišetić, 2009) te navedeni dodatni kriterij udaljenosti općinskoga/gradskog središta do $10 \mathrm{~km}$ od granice (Nejašmić, 2005; Nejašmić, 2008; Nejašmić i Toskić, 2015).

Demogeografska analiza u ovom radu upotrebljava jedinice lokalne samouprave (općine i gradove) kao temeljnu prostornu i statističku jedinicu analize. Njihov položaj u odnosu na vanjsku kopnenu granicu upotrijebljen je kao kriterij izdvajanja pograničnog područja. Sve općine/gradovi koji imaju doticaj s vanjskom granicom smatraju se pograničnima, a zajedno čine pogranično područje Republike Hrvatske. Prilikom posljednjeg popisa stanovništva 2011. takvih je upravnih jedinica bilo 128 (101 općina i 27 gradova). ${ }^{3}$

Slično tome, Zakon o područjima posebne državne skrbi također je za izdvajanje tzv. prve skupine, uz kriterij okupiranosti područja gradova/općina tijekom Domovinskog rata, kao dodatni kriterij upotrebljavao uvjet »da se nalaze neposredno uz državnu granicu, a gradsko/općinsko središte nije od državne granice udaljeno više od 15 kilometara zračne linije i nema više od 5000 stanovnika prema popisu pučanstva iz 1991. godine«, s izuzetkom Hrvatskog Podunavlja, iz kojeg su uključena sva tada okupirana područja (Narodne novine, 86/08, čl. 4, st. 1). Sporazum između Republike Hrvatske i Republike Slovenije o pograničnom prometu i suradnji iz 1997. navodi naselja koja čine pogranično područje dviju država. U Hrvatskoj je to 949 naselja u 49 općina/gradova, a u Sloveniji 1050 naselja u 34 općine (Narodne novine-Međunarodni ugovori, 15/97, 20/97). Sporazum između Republike Hrvatske i Bosne i Hercegovine o pograničnom prometu i suradnji potpisan 2003. uključivao je 74 općine/grada i 464 naselja iz Hrvatske te 27 općina i 394 naselja iz BiH (Narodne novine-Međunarodni ugovori, 3/05). Sporazum je stupio na snagu 20. travnja 2006., a prestao važiti 1. srpnja 2013. (Narodne novine-Međunarodni ugovori, 4/06, 5/13). Nova verzija Sporazuma iz 2013. uključuje 539 naselja iz Hrvatske (78 općina/gradova) i 485 naselja (26 općina) u BiH u pograničnom području koje se prostire u dubinu od pet kilometara od državne granice (Sporazum između RH i BiH o pograničnom prometu, 2013).

3 Neke se općine/gradovi protežu od granice dublje u unutrašnjost, dok se neke upravne jedinice nalaze vrlo blizu granice iako je ne dotiču (npr. Skrad, Ribnik, Desinić, Donji Kraljevec, Gornja Vrba, Dragalić, Slunj, Lokvičići i Zmijavci), no to je odraz i raščlanjenosti hrvatske granice na kopnu. Heterogenost pograničnog područja ilustrira i činjenica da kao dio Grada Dubrovnika naseljeni otoci Koločep, Lopud i Šipan također pripadaju pograničnom pojasu, kao i to da neke općine/gradovi koji izlaze na kopnenu granicu istovremeno imaju izlaz i na more: Slivno, Dubrovačko primorje, Dubrovnik, Župa dubrovačka i Konavle. Osim toga 29 općina/gradova Hrvatske ima izlaz na vanjsku granicu teritorijalnog mora (među njima su i četiri koji imaju i kopnenu granicu: Općina Dubrovačko primorje, Grad Dubrovnik, Općina Župa dubrovačka i Općina Konavle). Čitava bi se Hrvatska mogla smatrati pograničnim područjem: primjerice najudaljenija točka na kopnu od granice je udaljena svega oko $80 \mathrm{~km}$ (Rt Skala na području naselja Petrčana, Grad Zadar), a od jedinica regionalne (područne) samouprave jedino Grad Zagreb, Bjelovarsko-bilogorska i Požeško-slavonska županija nemaju doticaj s granicom. 
Tako izdvojeno područje koje obuhvaća općine/gradove koji neposredno dotiču granicu možemo definirati i užim pograničjem (usp. Pokos i Mišetić, 2009; Bognar i Bognar, 2010). ${ }^{4}$ Upotrebljavajući općine i gradove kao faktor izdvajanja pograničnog pojasa, u Hrvatskoj bismo mogli izdvojiti čak sedam zona udaljenosti jedinica lokalne samouprave od granice, poštujući uvjet da i svaki prelazak granice drugog JLS-a predstavlja novu zonu (slika $1) .^{5}$

Treća je razina obuhvata naseljski skup pograničnih naselja. On je obuhvatio sva naselja koja su u vrijeme popisa 2011. bila dio 128 pograničnih općina/gradova (njih 1877), a najuži pogranični pojas naselja obuhvatio je sva naselja čije područje dotiče vanjsku granicu. Takvih je naselja bilo 599 (tablica 1).

4 Radovi koji su za analizu upotrebljavali administrativno-teritorijalnu podjelu u vrijeme popisa 1991. također primjenjuju isti kriterij doticaja granice za određivanje pograničnog pojasa (Kržišnik-Bukić, 1995; Pokos, 1997) ili takav kriterij neznatno modificiraju (Kržišnik-Bukić, 1997a, 1997b; Repolusk, 1995, 1999; Josipovič i Kržišnik-Bukić, 2010). Na nižoj razini Horvat je za demogeografsku analizu slovensko-hrvatskog pograničja u sjeveroistočnoj Sloveniji izdvojio pet općina u kojima je upotrijebio razinu katastarskih općina koje je podijelio u četiri zone: 1) k. o. neposredno uz granicu, 2) k. o. udaljene najviše $5 \mathrm{~km}$ od granice, a bez kontakta s njom 3) k. o. udaljene najviše $10 \mathrm{~km}$ od granice i 4) ostale k. o. u pograničnim općinama (Horvat, 1993). U drugom radu Horvat i Počkaj Horvat izdvojili su četiri pogranične općine, čije su podatke po naseljima grupirali u katastarske općine (Horvat i Počkaj Horvat, 1994).

5 Prva zona JLS-a uz granicu označena je brojem nula (0), a svaka iduća povećava se za jedan. Otočni JLS-i spojeni mostom s kopnom tretirani su kao kopneni prema svom sjedištu (otoci Krk, Pag, Vir, Murter i Čiovo), a za ostale je primijenjen kriterij najkraće stalne brodske linije. Naselje Široko Polje, koje predstavlja eksklavu Grada Đakova, zbog svog je položaja u udaljenijoj kategoriji od matičnog područja (4 umjesto 2). Broj JLS-a prema kategorijama jest sljedeći: $0=128 ; 1=152 ; 2=126 ; 3=90 ; 4=39 ; 5=15 ; 6=6$. 
Slika 1. Pogranične zone prema udaljenosti općina/gradova od granice Hrvatske

Figure 1. Border zones according to the distance of municipalities/towns from the border of Croatia

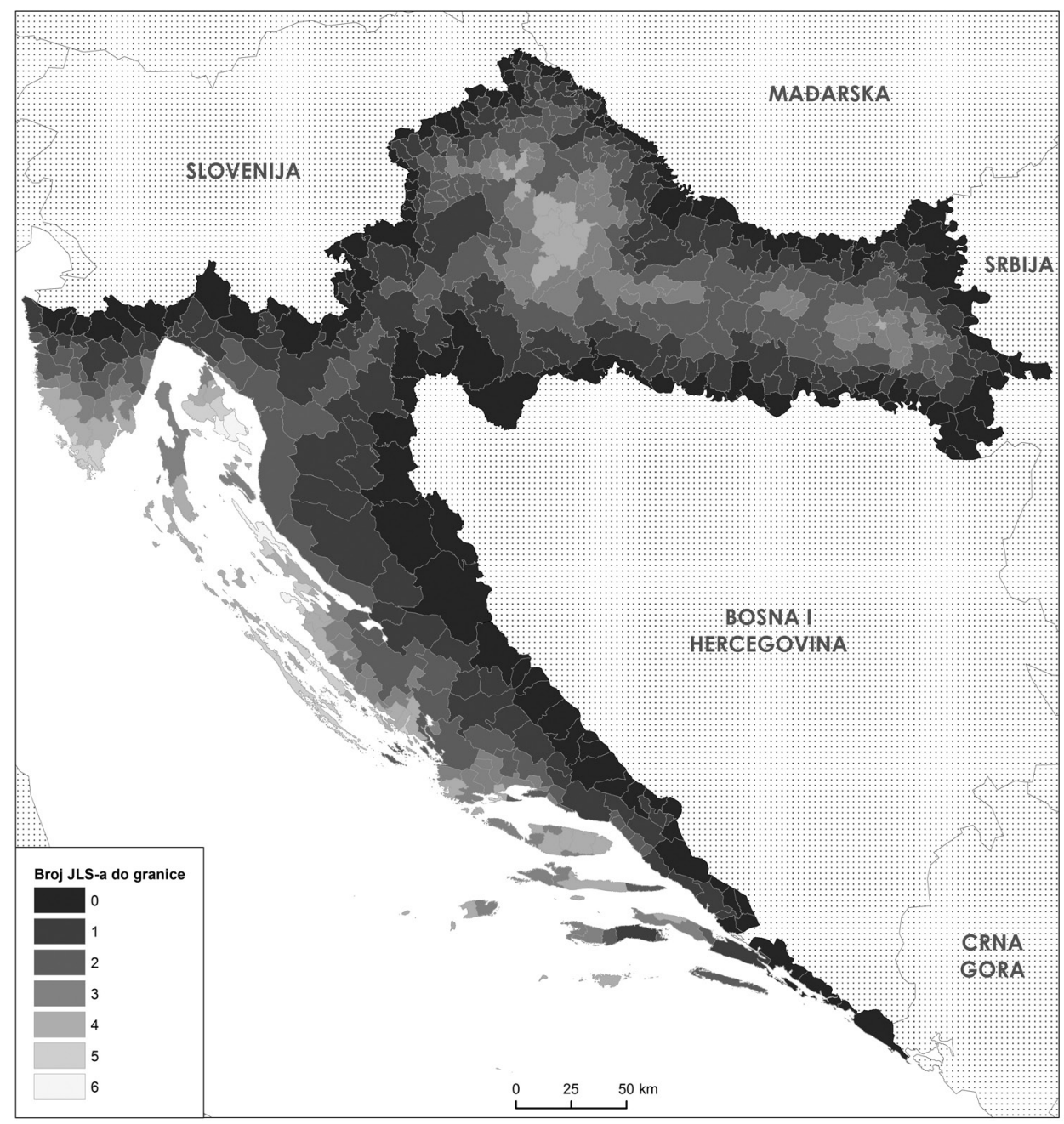




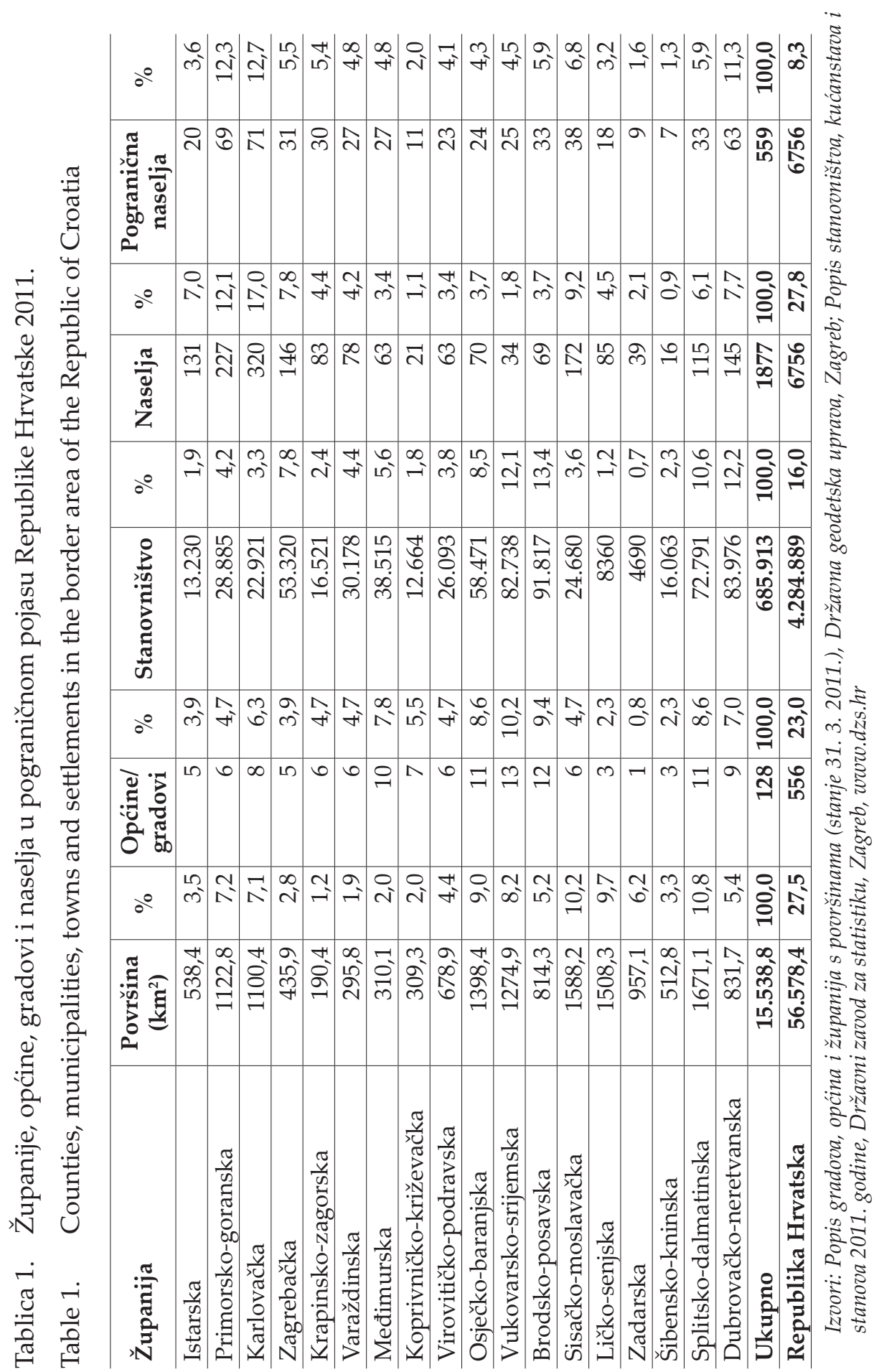




\subsection{Prostorni obuhvat}

Kod analize podataka na razini općina/gradova bilo je neophodno osigurati jednak teritorijalni opseg i strukturu statističkih jedinica u dva posljednja popisa (2001. i 2011.). To je učinjeno svođenjem na teritorijalni obuhvat posljednjeg popisa 2011. Za sva naselja koja su nakon popisa 2001. promijenila pripadnost (općini ili gradu) bilo je potrebno uskladiti (korigirati) podatke. Sedam naselja izdvojeno je iz Općine Žakanje te je pripalo novoj Općini Kamanje (Zakon o izmjeni i dopuni Zakona o područjima županija, gradova i općina u RH, Narodne novine, 175/03). Iz Grada Županje izdvojeno je naselje Štitar te je formirana istoimena općina (Zakon o područjima županija, gradova i općina u RH, Narodne novine, 86/06). Naselje Kupina promijenilo je pripadnost iz Općine Oprisavci u Općinu Velika Kopanica, a naselja Donji Babin Potok i Gornji Babin Potok iz Općine Plitvička Jezera u Općinu Vrhovine, koja nije u obuhvatu pograničja. Tako je za sedam općina/gradova bilo potrebno korigirati podatke, odnosno svesti ih na posljednji obuhvat.

Za još dvije općine (Domašinec i Slivno) bilo je potrebno procijeniti dio podataka. Naime dio naselja Turčišća izdvojen je iz Općine Domašinec te je pripao Općini Mala Subotica (izvan obuhvata pograničja), a dio naselja Trna iz Općine Slivno pripao je Gradu Opuzenu (također izvan obuhvata pograničja). ${ }^{6}$ Tako je procjena provedena za spomenuta dva naselja (Turčišć i Trn) te je ujedno upotrijebljena i za analizu ukupnoga kretanja stanovništva na razini naselja kod koje je bilo potrebno osigurati da svih 1877 naselja ima isti obuhvat. U Općini Gračac korigiran je (usklađen) podatak za naselje Srb, koje je nakon 2001. nastalo spajanjem naselja Donjeg Srba i Gornjeg Srba. Za ostalih deset naselja provedena je procjena. Iz dijela naselja Trnovca (Općina Nedelišće) izdvojen je dio iz kojeg je nastalo novo naselje Parag. U Općini Sveti Martin na Muri izdvajanjem i spajanjem dijelova triju postojećih naselja (Gornji Koncovčak, Grkaveščak i Jurovčak) formirano je novo naselje Toplice Sveti Martin, a istim promjenama u Općini Župa dubrovačka iz dijelova naselja Čelopeca, Čibače i Petrače nastalo je novo naselje Mandaljena. Devet je naselja samo promijenilo ime. Popisni podaci tako su korigirani za sedam općina/gradova, a procijenjeni za dvije općine te korigirani za jedno i procijenjeni za dvanaest naselja. Procjene za 2001.

${ }^{6}$ Iz dijela naselja Turčišća (Općina Domašinec), ali i dijelova naselja Držimurca (Općina Mala Subotica) i Gardinovca (Općina Belica), koji nisu u obuhvatu pograničja, nastalo je novo naselje Piškorovec u Općini Mala Subotica. Iz naselja Trna (Općina Slivno) izdvojen je dio iz kojeg je formirano novo naselje Pržinovac, koje je ujedno promijenilo pripadnost (Grad Opuzen). 
godinu provedene su prema omjerima iz 2011. prema kriteriju proporcionalnog odnosa. Po istom principu procijenjen je i podatak o dobnoj strukturi (kontingenti 0 - 19 i 60+) te kućanstvima za naselje Turčišće tj. Općinu Domašinec i naselje Trn. tj. Općinu Slivno. Kod podataka vitalne statistike (živorođeni i umrli) korigiran je (usklađen) podatak za Grad Samobor 2007. i 2008., kada je broj umrlih (živorođenih nije bilo) naselja Prekrižja Plešivičkog bio prikazan u Gradu Jastrebarskom ${ }^{7}$ te procijenjen podatak o živorođenima i umrlima za Općine Domašinec (naselje Turčišće) i Općinu Slivno (naselje Trn) za 2001. godinu. To je učinjeno za naselje Turčišće prema omjerima iz 2002., a za naselje Trn prema omjerima za razdoblje 2002. - 2010. jer su posrijedi mali brojevi. Na taj su se način osigurali jednak prostorni obuhvat i konstantnost granica 2001. - 2011.

\subsection{Izvori podataka}

Analiza se temelji na podacima službene statistike (popisi 2001. i 2011. te vitalna statistika, tj. podaci o živorođenima i umrlima 2001. - 2010.). Iako se oba posljednja popisa 2001. i 2011. temelje na konceptu »uobičajenog mjesta stanovanja«, oni nisu u punoj mjeri pogodni za usporedbu zbog toga što je popis 2001. u ukupni broj stanovnika uključivao i osobe koje su bile odsutne godinu i dulje ako su se u mjesto stalnog stanovanja vraćale sezonski i mjesečno (u popisu 2011. te osobe nisu bile uključene). Osim toga popis 2011. uzimao je u obzir i namjeru odsutnosti/prisutnosti kao dodatni kriterij za uključivanje u ukupni broj stanovnika nekog naselja ili isključivanje iz njega. Tako je ukupni broj stanovnika određenog naselja obuhvatio i osobe koje su u njega došle u proteklih dvanaest mjeseci uoči kritičnog trenutka popisa 2011. s namjerom da u njemu (kao mjestu uobičajenog stanovanja) ostanu barem godinu dana. $S$ druge strane, ukupni broj stanovnika nije obuhvatio i osobe koje su u Hrvatskoj imale prebivalište, ali su u kritičnom trenutku popisa bile odsutne kraće od dvanaest mjeseci, a namjeravale su biti odsutne dulje od jedne godine (pri čemu u Hrvatsku nisu dolazile tjedno) (Popis stanovništva, kućanstava i stanova 2011. godine, Metodološka objašnjenja).

Prema Zakonu o područjima županija, gradova i općina u RH iz 2006., naselje Prekrižje Plešivičko bilo je evidentirano u sastavu Grada Jastrebarskog (Narodne novine, 86/06), da bi Ustavni sud 2008. ukinuo takvu odredbu (Odluka Ustavnog suda Republike Hrvatske broj: U-I-3226/2006 od 9. srpnja 2008., Narodne novine, 95/08). 


\section{OPĆE (UKUPNO) KRETANJE STANOVNIŠTVA HRVATSKOG POGRANIČJA}

Pogranični pojas prostire se na površini od $15.538,8$ km², što čini $27,5 \%$ kopnenog dijela Hrvatske. Prilikom popisa 2011. u njemu je živjelo 685.913 ili 16,0\% stanovništva Hrvatske (2001. 738.136 stan. ili 16,6\%). Temeljni demografski proces, kako čitave zemlje tako i ovog dijela Hrvatske, između popisa 2001. i 2011. bila je depopulacija. Smanjenje se u pograničju odvijalo intenzivnije te je iznosilo 7,1\%, dok je istovremeno u ostalom dijelu Hrvatske (bez pograničja) iznosilo 2,7\%, a Hrvatske u cjelini 3,4\%. Hrvatska je u prosjeku 2011. bila znatno gušće naseljena $\left(75,7 \mathrm{st} / \mathrm{km}^{2}\right)$ od pograničnog pojasa $\left(44,1 \mathrm{st} / \mathrm{km}^{2}\right)$. Ako pograničju suprotstavimo samo ostali dio Hrvatske, čija je prosječna gustoća naseljenosti iznosila $87,7 \mathrm{st} / \mathrm{km}^{2}$, razlika je gotovo dvostruka. Glavni uzrok depopulacije bio je negativan migracijski saldo (-32.484 od 2001. do 2011.), dok je sekundarni uzrok prirodni pad (-19.739; 70.197 živorođenih i 89.936 umrlih od 2001. do 2010.). Njihov učinak na depopulaciju djelovao je u omjeru $62,2 \%: 37,8 \%$. Iako kod Hrvatske u cjelini i dijelu bez pograničja također zajednički djeluju obje nepovoljne sastavnice ukupnoga kretanja stanovništva, njihov je utjecaj obrnut. Kod Hrvatske je prirodni pad sudjelovao sa $62,3 \%$, a kod dijela koji nije uz državnu granicu s čak $75,0 \%$.

\subsection{Opće kretanje stanovništva pograničnih općina/gradova}

Od ukupno 556 općina i gradova Hrvatske (prema popisu 2011.), 128 jedinica lokalne samouprave $(23,0 \%)$ nalazi se u pograničnom pojasu. Sa Slovenijom graniči 39 općina/gradova, s Mađarskom 26, sa Srbijom 12, s BiH 54 te jedna općina s Crnom Gorom. Od toga četiri općine graniče istovremeno s dvije države: Općina Podturen (Međimurska županija) sa Slovenijom i Mađarskom, Općina Draž (Osječko-baranjska županija) s Mađarskom i Srbijom, Općina Drenovci (Vukovarsko-srijemska županija) sa Srbijom i Bosnom i Hercegovinom te Općina Konavle (Dubrovačka županija) s Bosnom i Hercegovinom te Crnom Gorom (tablica 2). Većina pograničnih jedinica lokalne samouprave već je bila prepoznata kao prostor zaostajanja u razvoju, pa ih tako 73 ima status područja posebne državne skrbi, ${ }^{8}$ a trinaest općina ima status brdsko-planinskog područja (osam prema Sloveniji i pet prema $\mathrm{BiH}$ ) (Zakon o područjima posebne državne skrbi, Narodne novine,

Od toga su 29 u prvoj skupini, 7 gradova/općina u drugoj skupini (Grad Dubrovnik dio) te ostalih $37 \mathrm{u}$ trećoj skupini na temelju kriterija zaostajanja u ekonomskome, strukturnom i demografskom razvoju. 
86/08; Zakon o izmjenama i dopunama Zakona o brdsko-planinskim područjima, Narodne novine, 117/03).

Tablica 2. Pogranične općine/gradovi i naselja u Hrvatskoj

Table 2. Border municipalities/towns and settlements in Croatia

\begin{tabular}{lcc}
\hline Granica & $\begin{array}{c}\text { Broj općina/ } \\
\text { gradova }\end{array}$ & Broj naselja \\
\hline Slovenija & 38 & 255 \\
\hline Slovenija/Mađarska & 1 & 1 \\
\hline Mađarska & 24 & 52 \\
\hline Mađarska/Srbija & 1 & 1 \\
\hline Srbija & 10 & 26 \\
\hline Srbija/BiH & 1 & 1 \\
\hline BiH & 52 & 216 \\
\hline BiH/Crna Gora & 1 & 1 \\
\hline Crna Gora & - & 6 \\
\hline Ukupno & $\mathbf{1 2 8}$ & $\mathbf{5 5 9}$ \\
\hline
\end{tabular}

Depopulacija je temeljni demografski proces i u većini općina/gradova. U posljednjemu međupopisju zahvatila je 108 JLS-a $(84,4 \%)$, dok se u ostalih dvadeset broj stanovnika povećao (slika 2). Raščlamba općega kretanja po komponentama upućuje na to da je prirodni pad djelovao u čak 110 JLS-a (u osamnaest je djelovao prirodni prirast) (slika 3). Istovremeno, negativni migracijski saldo ostvaren je u 99 općina i gradova (u 28 je bio pozitivan, a u jednom nulti). Kao i kod pograničja u cjelini, glavni je uzrok depopulacije iseljavanje, tj. negativni migracijski saldo. Među depopulacijskim općinama/gradovima u najvećem broju slučajeva (86) zajednički su djelovali negativni migracijski saldo (kod 49 JLS-a vodeći čimbenik) i prirodni pad (dominanta u 37 JLS-a). Kod dvanaest jedinica ukupnu depopulaciju isključivo uzrokuje negativni migracijski saldo (jer je na snazi prirodni prirast), a u njih deset depopulacija se javlja kao rezultat prirodnog pada (migracijski saldo je pozitivan ili nulti). 
Slika 2. Opće kretanje stanovništva hrvatskog pograničja 2001. - 2011. po općinama/gradovima

Figure 2. Population change of municipalities/towns in the Croatian borderland, 2001-2011

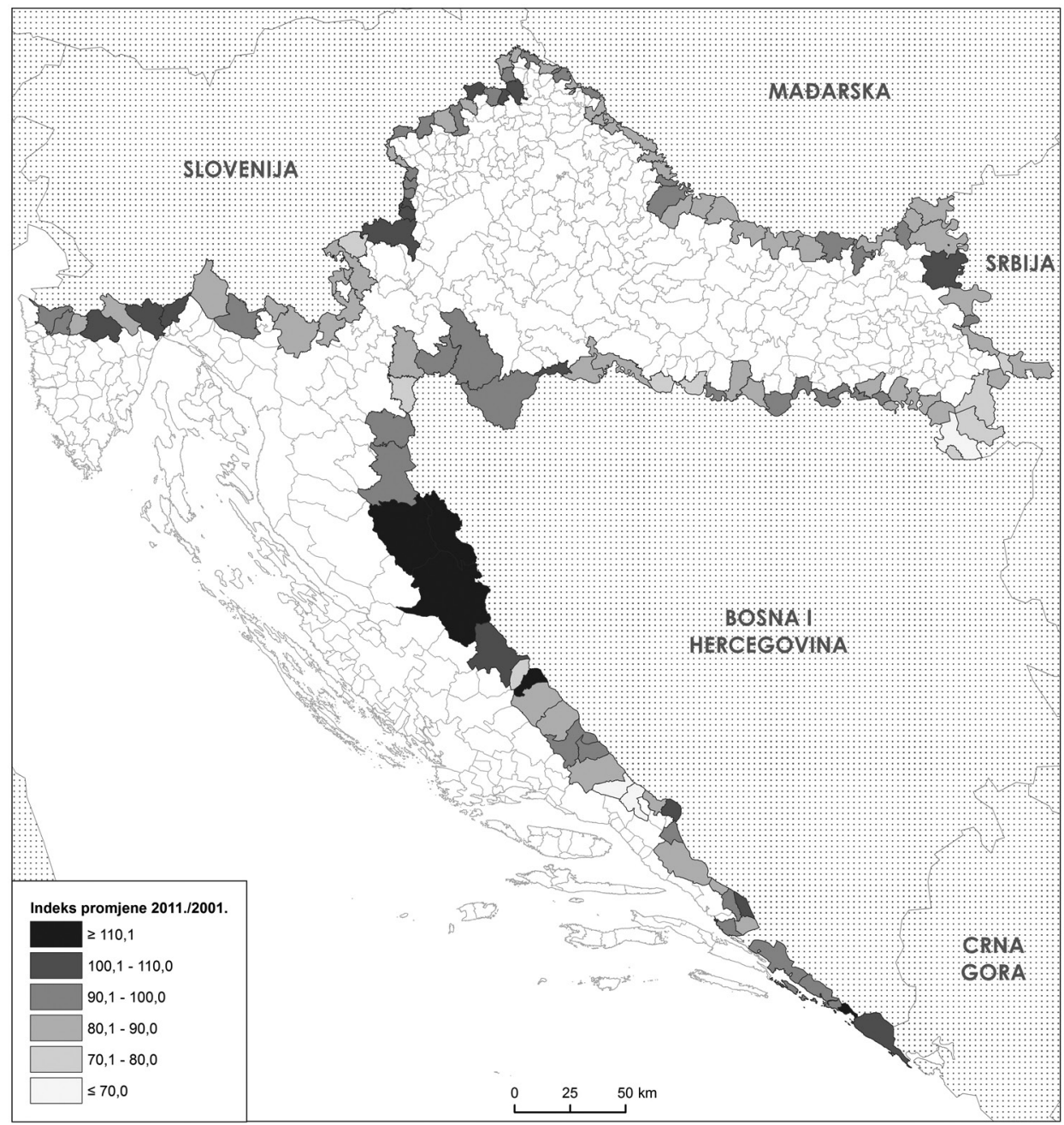

Izvori: Popis stanovništva, kućanstava i stanova, 31. ožujka 2001., Državni zavod za statistiku Zagreb, wwww.dzs.hr; Popis stanovništva, kućanstava i stanova 2011. godine, Državni zavod za statistiku, Zagreb, www.dzs.hr

Najveće relativno smanjenje zabilježeno je u općinama s intenzitetom depopulacije preko 20\%: Cista Provo (-36,4\%), Lovreć (-32,0\%), Drenovci $(-30,3 \%)$, Cetingrad (-26,2\%), Gunja (-25,8\%), Žumberak (-25,5\%), Vrbanja 
$(-23,9 \%)$, Vrbje $(-23,8 \%)$, Lovas (-23,1\%), Kijevo (-21,8\%), Nijemci (-21,6\%) i Stara Gradiška (-20,6\%). Sve su one prepoznate kao područja posebne državne skrbi, a Općina Žumberak kao brdsko-planinsko područje. Valja napomenuti da su među njima i općine s najintenzivnijom depopulacijom u Hrvatskoj. Općine Cista Provo, Lovreć i Drenovci zauzimaju prva tri mjesta, a Cetingrad, Gunja i Žumberak sedmo, osmo i deveto mjesto.

Slika 3. Prirodno kretanje stanovništva hrvatskog pograničja 2001. 2011. po općinama/gradovima

Figure 3. Natural change of population in Croatian borderland according to municipalities/towns, 2001-2011

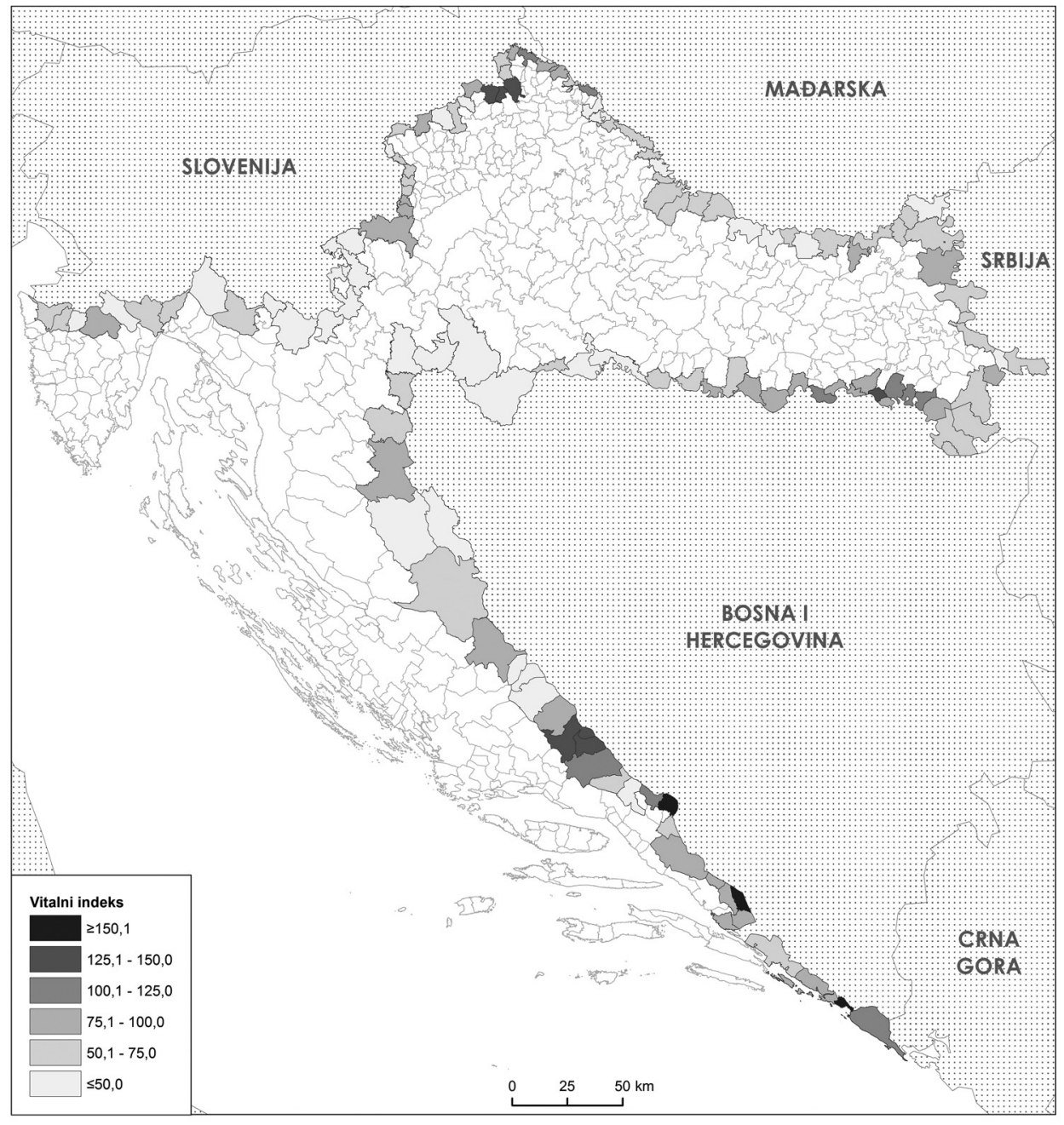

Izvor: Tablogrami rođeni i umrli po naseljima, Državni zavod za statistiku, Zagreb 
Porastom se ističe Općina Župa dubrovačka (25,0\%), zatim Grad Metković $(9,1 \%)$, Općina Brdovec (8,2\%), Općina Marija Gorica (6,9\%), Općina Matulji (6,7\%), kao i općine s najvećim stopama neto migracijskog salda u kojima je doseljavanje rezultat povratka ratnih izbjeglica (Civljane 74,5\%, Gračac 19,6\%, Udbina 13,6\% i Donji Lapac 12,4\%) (usp. Nejašmić i Toskić, 2015). U općinama/gradovima s porastom populacije glavni je generator rasta doseljavanje. Kod svih je migracijski saldo bio pozitivan, osim u Gradu Imotskom. U četrnaest općina/gradova on anulira prirodni pad, a u pet slučajeva djeluje zajedno s prirodnim prirastom (od čega u dvije općine - Župi dubrovačkoj i Konavlima - premašuje vrijednosti pozitivnoga prirodnoga kretanja, dok je u općinama Nedelišće i Sračinec te Gradu Metkoviću bilo obrnuto). Smjer općega kretanja stanovništva ostavlja trag i na gustoći naseljenosti, tako da na ovom području postoje velike razlike koje se kreću u rasponu od općine Lanišće $\left(2,3 \mathrm{st} / \mathrm{km}^{2}\right)$, koja je uz općine Udbina (2,7 st/ $\left.\mathrm{km}^{2}\right)$ i Civljane $\left(2,9 \mathrm{st} / \mathrm{km}^{2}\right)$ najrjeđe naseljen JLS u zemlji, do Grada Slavonskog Broda (1088,8 st/km²), koji je nakon Rijeke, Splita i Zagreba najgušće naseljen JLS u Hrvatskoj (slika 4). 
Slika 4. Gustoća naseljenosti hrvatskog pograničja 2011. po općinama/ gradovima

Figure 4. Population density of municipalities/towns in the Croatian borderland, 2011

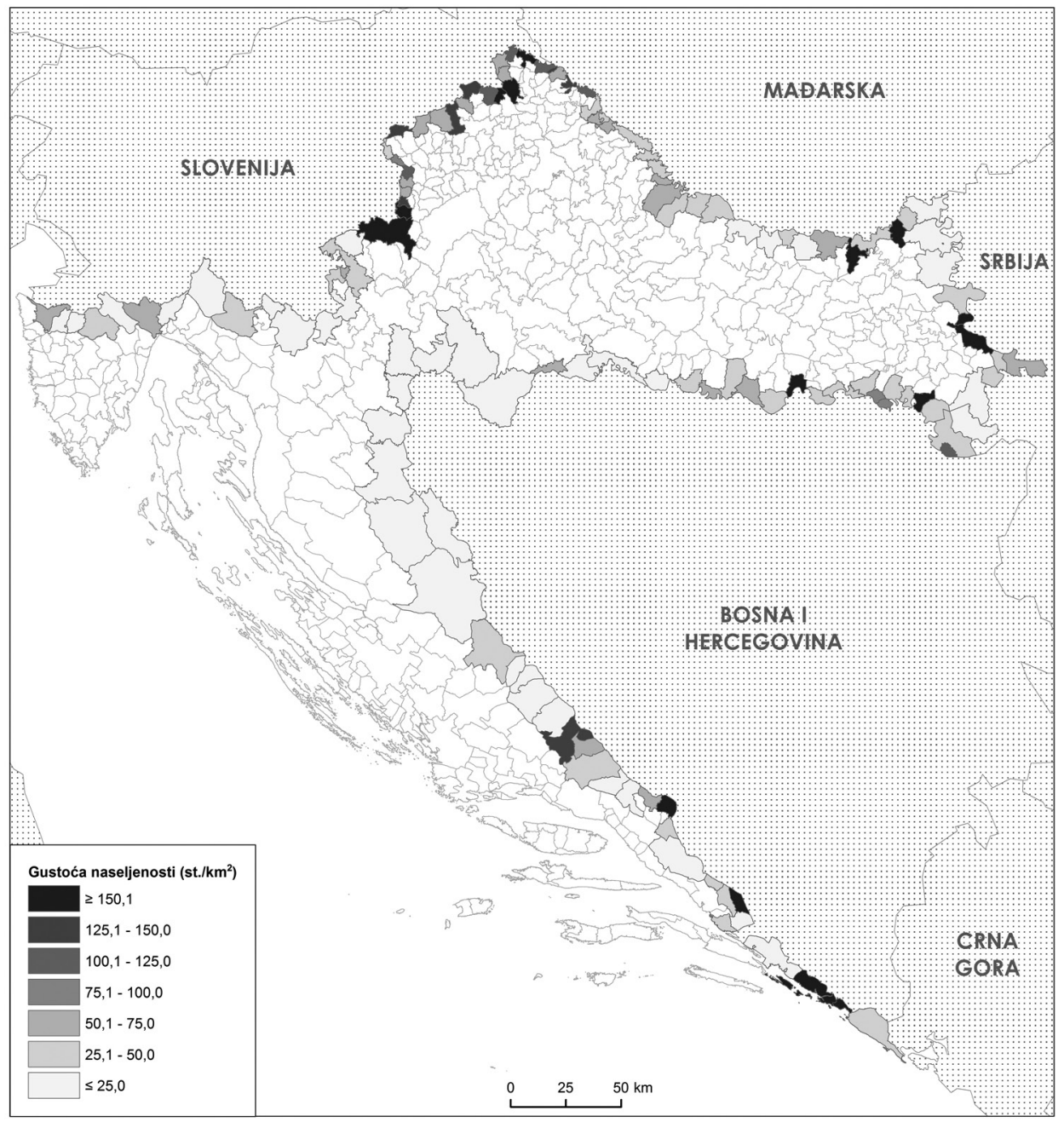

Izvori: Popis stanovništva, kućanstava i stanova 2011. godine, Državni zavod za statistiku, Zagreb, wwww.dzs.hr; Popis gradova, općina $i$ županija s površinama, Državna geodetska uprava, Zagreb 


\subsection{Opće kretanje stanovništva pograničnih naselja}

Od 6756 naselja RH 2011. u pograničnom pojasu nalazi se njih 1877 ili $27,8 \%$. Kao dio naslijeđa, naseljska struktura pograničja takva je da prevladavaju mala naselja. U kategoriji do 100 stanovnika čak je 50,2\% naselja (na razini RH 39,3\%). Među njima su najbrojnija patuljasta (1 - 49), kojih ima $34,8 \%$, a u njima živi samo $2,0 \%$ stanovnika. Sitnih naselja (50 - 100) ima 15,5\%, a malih (101 - 200) 15,6\% (tablica 3). Patuljastih naselja (1 - 49 stan.) ima najviše u pograničju prema slovenskoj granici (391 naselje). Među županijama se ističu Karlovačka (ukupno 183 na obje granice, prema Sloveniji i BiH; samo Grad Ozalj 59) i Primorsko-goranska županija (126; ističe se Grad Vrbovsko s 42), a prisutnošću sitnih naselja (50 - 100) također Karlovačka županija (52).

Tablica 3. Naselja hrvatskog pograničja 2011. prema veličini

Table 3. Settlements of the Croatian borderland in 2011 by size

\begin{tabular}{crrrr}
\hline \multirow{2}{*}{ Veličina naselja } & \multicolumn{2}{c}{ Broj } & \multirow{2}{*}{ Broj } & \multicolumn{2}{c}{ Udio (\%) } \\
\cline { 4 - 6 } & naselja & stanovnika & naselja & stanovnika \\
\hline Bez stanovnika & 61 & - & 3,2 & - \\
\hline $1-49$ & 653 & 13.792 & 34,8 & 2,0 \\
\hline $50-100$ & 290 & 21.122 & 15,5 & 3,1 \\
\hline $101-200$ & 293 & 42.362 & 15,6 & 6,2 \\
\hline $201-500$ & 330 & 103.834 & 17,6 & 15,1 \\
\hline $501-1000$ & 147 & 106.295 & 7,8 & 15,5 \\
\hline $1001-1500$ & 33 & 39.575 & 1,8 & 5,8 \\
\hline $1501-2000$ & 22 & 38.319 & 1,2 & 5,6 \\
\hline $2001-5000$ & 33 & 104.098 & 1,8 & 15,2 \\
\hline $5001-10.000$ & 7 & 42.597 & 0,4 & 6,2 \\
\hline $10.001-20.000$ & 5 & 65.486 & 0,3 & 9,5 \\
\hline $20.001-50.000$ & 2 & 54.902 & 0,1 & 8,0 \\
\hline $50.001-60.000$ & 1 & 53.531 & 0,1 & 7,8 \\
\hline Ukupno & $\mathbf{1 8 7 7}$ & $\mathbf{6 8 5 . 9 1 3}$ & $\mathbf{1 0 0 , 0}$ & $\mathbf{1 0 0 , 0}$ \\
\hline
\end{tabular}

Izvor: Popis stanovništva, kućanstava i stanova 2011. godine, Državni zavod za statistiku, Zagreb, ww.dzs.hr

Čak 72,3\% naselja (1357) smanjilo je broj stanovnika od 2001. do 2011., a 26 ih je u istom razdoblju »izumrlo« (slika 5). U 403 naselja broj stanovnika se povećao, $u$ jedanaest ih je na djelu repopulacija jer su u 2001. bili bez stanovnika, a u 45 je broj stanovnika stagnirao. Bez stanovnika u oba popisa (tzv. mrtva sela) bilo je 35 naselja, tako da je uz 26 novih njihov broj narastao s 46 na 61 (40,7\% od 150 naselja bez stanovnika u RH). 
Slika 5. Opće kretanje stanovništva hrvatskog pograničja 2001. - 2011. po naseljima

Figure 5. Population change of the settlements in the Croatian borderland, 2001-2011

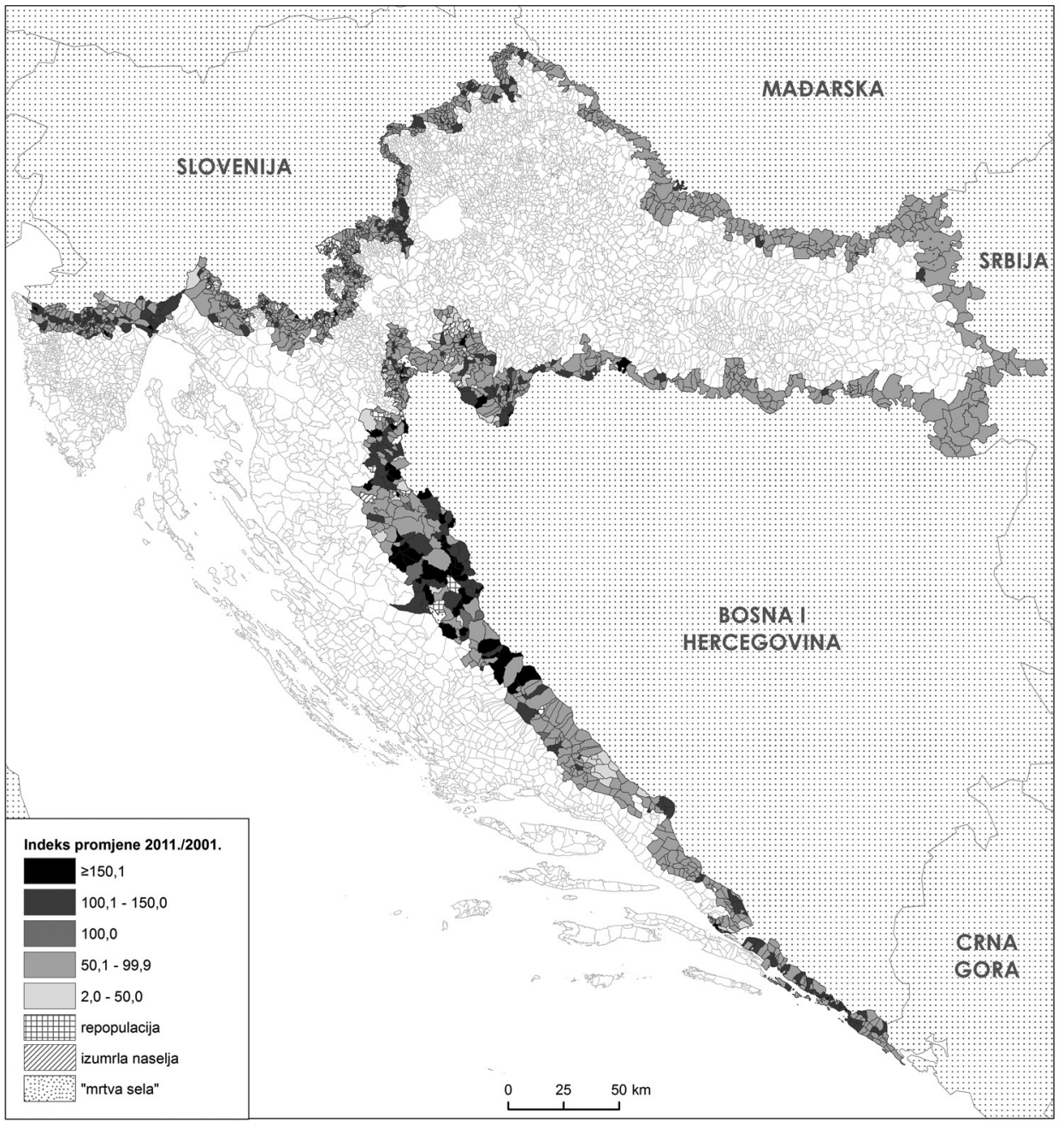

Izvori: Popis stanovništva, kućanstava i stanova, 31. ožujka 2001., Državni zavod za statistiku, Zagreb, www.dzs.hr; Popis stanovništva, kućanstava i stanova 2011. godine, Državni zavod za statistiku, Zagreb, wwww.dzs.hr

Najbrojnija su u pograničnom dijelu prema Sloveniji (43), posebice u Primorsko-goranskoj županiji (ukupno 27; npr. Općina Brod Moravice jeda- 
naest, Grad Delnice devet) i tom dijelu Karlovačke županije (ukupno deset; npr. Grad Ozalj osam) (slika 5). Na primjeru pograničja potvrdilo se pravilo da što je naselje manje, to je veća vjerojatnost da će postati još manje. U pet najmanjih kategorija indeks promjene povećavao se sukladno veličini razreda. Tako su patuljasta naselja $(1-49)$ imala smanjenje $-14,6 \%$, mala naselja (50 - 100) -12,6\%, (101 - 200) -11,9\%, (201 - 500) -9,4\% i (501 - 1000) -6,0\%.

\subsubsection{Opće kretanje stanovništva užega pograničnog područja naselja}

Neposredno na hrvatsku granicu izlazi 559 naselja, i to 256 na kopnenu granicu sa Slovenijom, 54 na granicu s Mađarskom, 28 na granicu sa Srbijom, 218 na granicu s BiH te sedam na granicu s Crnom Gorom. Među njima su i četiri naselja koja izlaze na dvije granice: Novakovec (Općina Podturen) na granicu sa Slovenijom i Mađarskom, Draž (Općina Draž) na granicu s Mađarskom i Srbijom, Račinovci (Općina Drenovci) na granicu sa Srbijom i Bosnom i Hercegovinom te Dubravka (Općina Konavle) na granicu s Bosnom i Hercegovinom i Crnom Gorom (tablica 2). U strukturi naselja užeg pojasa također prevladavaju patuljasta $(29,2 \%)$, sitna $(12,0 \%)$ i mala naselja (16,8\%) (tablica 4). U njima je 2011. popisano svega 7,2\% stanovnika iako su zajedno činili 58,0\% naseljskog skupa. Ovaj najuži pojas ujedno bilježi najveće smanjenje od izdvojenih i analiziranih cjelina, koje je iznosilo 8,6\% (s 339.594 stanovnika na 306.983).

Od 559 naselja u užem području neposredno uz granicu, čak 431 ih je depopuliralo $(77,1 \%)$, tri su ostala bez stanovnika, 102 su zabilježila porast $(18,2 \%)$, četiri su »oživjela«, deset ih stagnira, a devet je bilo bez stanovnika u oba posljednja popisa ( $\mathrm{zv}$. mrtva sela).

U hrvatsko-slovenskom pograničju ističe se nekoliko depopulacijskih zona. Područje Grada Čabra, gdje je zahvaćeno svih šesnaest naselja plus naselje Hrvatsko u Gradu Delnicama, zatim Općina Žakanje, gdje četrnaest pograničnih naselja depopulira (dvanaest u nizu), te kontinuirana zona od 26 naselja u Krapinsko-zagorskoj županiji. Taj se pojas proteže od Grada Klanjca te općina Kumrovec, Zagorska Sela i Hum na Sutli, u kojima sva 24 pograničnih naselja bilježe smanjenje, te uključuje i dva naselja iz Općine Kraljevec na Sutli. Druga depopulacijska zona proteže se manjim dijelom uz hrvatsko-slovensku granicu te se većim dijelom nastavlja uz hrvatskomađarsku granicu, a čine je 22 naselja. Od naselja Peklenice na području Grada Murskog Središća do naselja Pitomače $u$ istoimenoj općini. Dio su tog pojasa i svih jedanaest pograničnih naselja Koprivničko-križevačke županije. 
Tablica 4. Uži pojas naselja hrvatskog pograničja prema veličini 2011.

Table 4. The narrowest zone of the settlements of the Croatian borderland in 2011 by size

\begin{tabular}{crrrr}
\hline \multirow{2}{*}{ Veličina naselja } & \multirow{2}{*}{$\begin{array}{c}\text { Broj } \\
\text { naselja }\end{array}$} & Broj & \multicolumn{2}{c}{ Udio (\%) } \\
\cline { 4 - 6 } & stanovnika & naselja & stanovnika \\
\hline Bez stanovnika & 12 & - & 2,1 & - \\
\hline $1-49$ & 163 & 3424 & 29,2 & 1,1 \\
\hline $50-100$ & 67 & 4936 & 12,0 & 1,6 \\
\hline $101-200$ & 94 & 13.776 & 16,8 & 4,5 \\
\hline $201-500$ & 115 & 36.893 & 20,6 & 12,0 \\
\hline $501-1000$ & 62 & 45.517 & 11,1 & 14,8 \\
\hline $1001-1500$ & 17 & 20.871 & 3,0 & 6,8 \\
\hline $1501-2000$ & 8 & 14.230 & 1,4 & 4,6 \\
\hline $2001-5000$ & 13 & 37.904 & 2,3 & 12,3 \\
\hline $5001-10.000$ & 4 & 22.014 & 0,7 & 7,2 \\
\hline $10.001-20.000$ & 2 & 27.419 & 0,4 & 8,9 \\
\hline $20.001-50.000$ & 1 & 26.468 & 0,2 & 8,6 \\
\hline $50.001-60.000$ & 1 & 53.531 & 0,2 & 17,4 \\
\hline Ukupno & 559 & $\mathbf{3 0 6 . 9 8 3}$ & $\mathbf{1 0 0 , 0}$ & $\mathbf{1 0 0 , 0}$ \\
\hline
\end{tabular}

Izvor: Popis stanovništva, kućanstava i stanova 2011. godine, Državni zavod za statistiku, Zagreb

Uz hrvatsko-mađarsku, hrvatsko-srpsku te hrvatsko-bosanskohercegovačku granicu prostire se najduža kontinuirana depopulacijska zona od čak 103 naselja. Ta se zona proteže od naselja Starogradačkog Marofa u Općini Pitomača do Gornjeg Varoša u Općini Stara Gradiška i obuhvaća 42 općine/ grada te sva pogranična naselja u Osječko-baranjskoj (24), Vukovarsko-srijemskoj (25), Brodsko-posavskoj (33) te gotovo sva u Virovitičko-podravskoj županiji (21 od 23). Broj stanovnika u toj zoni smanjio se za 13,0\% (u apsolutnom iznosu 26.667, tj. s 205.677 na 179.010).

Zona rasta ističe se duž hrvatsko-bosanskohercegovačke granice: Grad Dubrovnik i Općina Župa dubrovačka (sedamnaest naselja, a naselja Donji Brgat i Grbavac praktički stagniraju). 


\section{DOBNA STRUKTURA STANOVNIŠTVA HRVATSKOG POGRANIČJA}

Osim što je, uz strukturu prema spolu, najvažnije obilježje neke populacije, sastav prema dobi važan je pokazatelj prošlih demografskih procesa. Stoga je $u$ analizama depopulacijskih područja potrebno uključiti i razmatranje dobne strukture s naglaskom na procesu i pokazateljima starenja. Prema indeksu starosti kao pokazatelju ostarjelosti stanovništva, pograničje je na početku promatranog razdoblja, 2001. godine, bilo u nešto povoljnijem položaju (88,6 naspram 91,2 RH). Proces starenja, prema istom indikatoru, sporije se odvijao u graničnom pojasu, jer se indeks 2011. povećao na 108,9 (za 20,3), dok se na ostalom području povećao na 116,3 (za 25,1). U isto vrijeme vrijednost indeksa za čitavu Hrvatsku povećala se za 24,3 (90,7 $\rightarrow$ 115,0). Prema drugom pokazatelju (koeficijentu starosti), udio starih u ukupnoj populaciji povećao se u pograničnoj zoni s $22,0 \%$ na $24,0 \%$, a u ostalom dijelu Hrvatske s $21,4 \%$ na $24,1 \%$. Istovremeno, udio mladih smanjio se u pograničju s $24,8 \%$ na $22,0 \%$, a drugdje s $23,5 \%$ na $20,7 \%$.

Starenje je u pograničju prije svega rezultat smanjivanja broja i udjela mladog stanovništva. Njihov se ukupni broj u deset godina relativno smanjio za $17,5 \%$, a broj starih istovremeno se povećao za $1,5 \%$. Proces smanjivanja mladog stanovništva sporiji je u ostalom dijelu Hrvatske (-14,3\%), no, s druge strane, broj starog stanovništva znatno se brže povećava izvan pograničnog pojasa $(+9,3 \%)$. Karakteristika hrvatskog pograničja jest i kasnija feminizacija starenja. Ona ovdje počinje od kontingenta 60 - 64, dok je u ostalom dijelu prisutna već od skupine 40 - 44, a u čitavoj Hrvatskoj od dobi $45-49$.

Na početku analiziranog razdoblja, prema popisu 2001., 57 općina/gradova imalo je više starog no mladog stanovništva, da bi se u svega deset godina njihov broj povećao na 87 . U čak 115 općina i gradova indeks starosti se do 2011. povećao, a u samo trinaest smanjio. Glavni uzrok povećanja indeksa na ovoj razini također je smanjenje mladog stanovništva. Naime u 76 općina/gradova indeks se povećao pod utjecajem istovremenog smanjenja mladog i starog stanovništva, pri čemu se mladi smanjuju po većoj stopi od starog stanovništva, a u još dvadeset općina/gradova stopa smanjenja mladog stanovništva veća je od stope povećanja starog stanovništva. Depopulacija mladoga kontingenta ostvarila se u čak 122 JLS-a (95,3\%), dok se broj mladih povećao u samo šest općina/gradova (Civljane, Gračac, Udbina, Župa dubrovačka, Klana i Imotski). Relativno najveće smanjenje mlade populacije ostvareno je u općinama Lanišće (45,9\%), Cista Provo (43,4\%) i Opr- 
talj $(43,2 \%)$. Najstarija je populacija u Općini Civljane, koja je ujedno imala najstarije stanovništvo u čitavoj Hrvatskoj (indeks starosti 1086,7, koeficijent starosti $68,2 \%)$ te Općini Žumberak $(407,1 ; 45,6 \%)$, dok je najmlađe pučanstvo u Gradu Imotskom (indeks starosti 58,0), koji je bio najmlađi upravni grad u Hrvatskoj prema tom pokazatelju 2011. godine (peti najmlađi JLS) (slika 6). Istovremeno, koeficijent starosti povećao se u 86 općina/gradova, a smanjio u 42, s time da se u svih trinaest JLS-a u kojima se vrijednost indeksa starosti smanjila ujedno smanjio i koeficijent starosti. 
Slika 6. Dobna struktura stanovništva hrvatskog pograničja 2011. po općinama/gradovima

Figure 6. Age structure of the population of municipalities/towns in the Croatian borderland, 2011

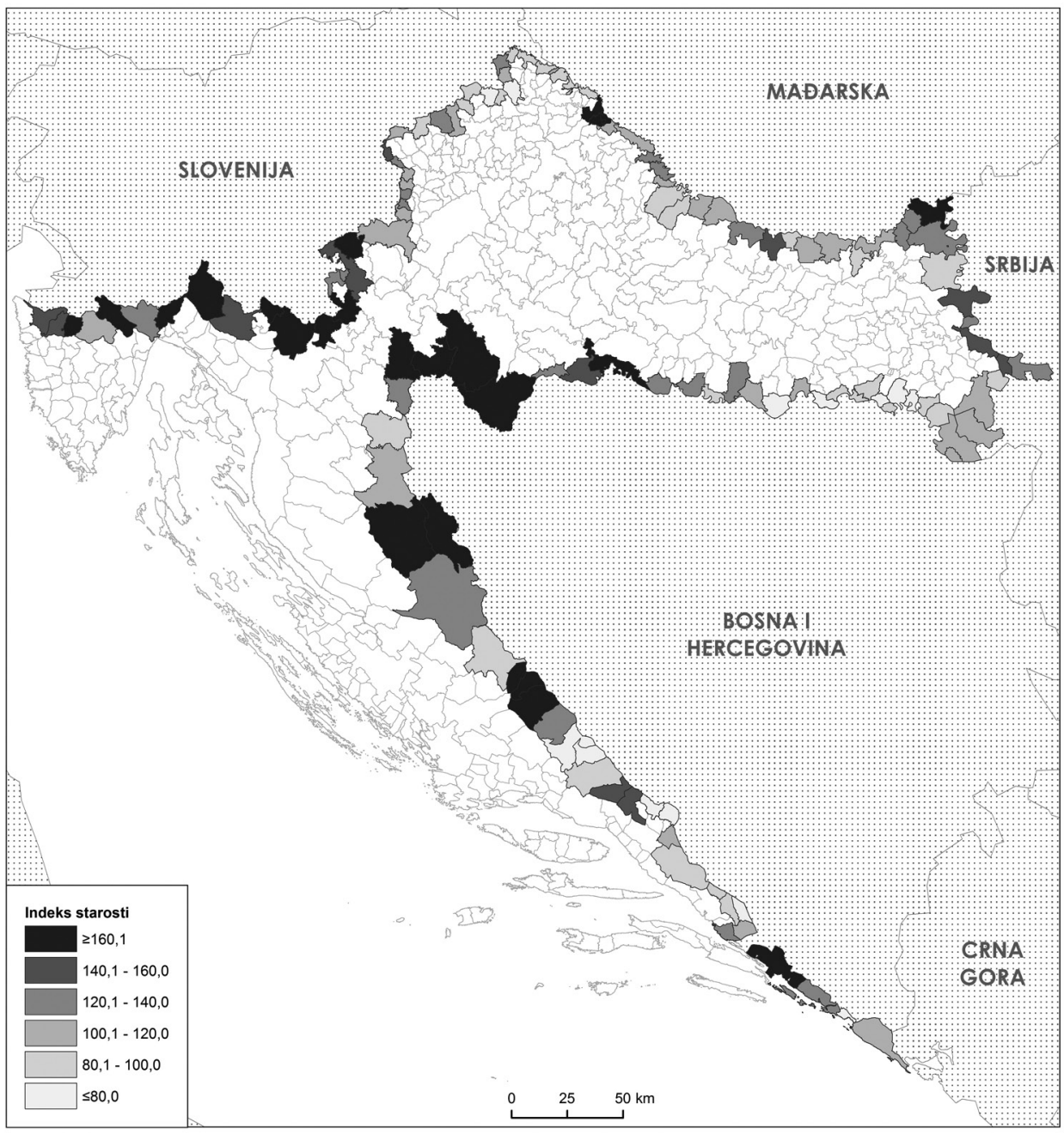

Izvor: Popis stanovništva, kućanstava i stanova 2011. godine, Državni zavod za statistiku, Zagreb, www.dzs.hr 


\section{SASTAV KUĆANSTAVA HRVATSKOG POGRANIČJA}

Struktura kućanstava uglavnom je odraz demografskih kretanja, a iz njenih promjena može se vidjeti i vitalnost određenoga kraja. ${ }^{9}$ Zbog njihove povezanosti s procesom starenja, $\mathrm{u}$ analizi su izdvojena samačka kućanstva. Na razini pograničja udio samačkih kućanstava se u ukupnom broju povećao i iznosi nešto manje od četvrtine (2011. $=23,3 \%$; 2001. $=20,8 \%$ ), a njihov udio u ostalim kućanstvima manji je od Hrvatske u cjelini $(24,6 \%)$ i od Hrvatske koja nije u pograničnoj zoni $(24,8 \%)$. Kako se ukupni broj samačkih kućanstava povećao za 4295, proizlazi da sve više stanovnika živi samo. U pograničju je 2011. godine 53.826 stanovnika ili 7,8\% živjelo u samačkom kućanstvu (2001. godine 6,7\% stanovnika). Struktura samačkih kućanstava prema spolu upućuje na to da u njima živi pretežno starija ženska populacija $(60,5 \%$ Ž i 39,5\% M). Udio ženske populacije koja živi u samačkim kućanstvima $(9,3 \%)$ očekivano je viši od muške samačke populacije $(6,3 \%)$.

Prosječni broj članova u kućanstvu kretao se od 4,0 (Grad Imotski) do 1,9 (Općina Civljane). Najveći udio samačkih kućanstava zatečen je 2011. u općinama Kijevo (51,0\%), Civljane (45,3\%), Žumberak (42,9\%) i Lanišće $(40,1 \%)$, a najmanji u općinama/gradovima Petrijanec (14,5\%), Imotski $(15,0 \%)$, Sračinec $(15,3 \%)$, Nedelišće $(15,4 \%)$. Samo se u osamnaest općina udio samačkih kućanstava smanjio, a u ostalih 110 JLS-a se povećao. Najveće relativno povećanje ostvareno je u Gradu Vrlici (10,0\%) te općinama Žumberak (9,6\%), Jasenovac (8,4\%) i Kula Norinska (8,2\%).

Iako je udio samačkih kućanstava u pograničnom pojasu nešto manji nego u ostalom dijelu države, gotovo dvije trećine (ili preciznije 65,4\%) samačkih kućanstava pograničja čini stanovništvo starije životne dobi (60 i više), što je znatnije od ostalog dijela Hrvatske bez pograničja $(58,9 \%)$ ili državnog prosjeka (59,9\%). Ako taj kontingent raščlanimo na petogodišnje dobne skupine, najbrojniji su oni u dobi 75 - 79 (22,5\% kućanstava u dobi 60+ i 14,7\% svih samačkih kućanstava), a potom 70 - 74 (21,3\% odnosno $13,9 \%)$. Raspon udjela starijih (60+) u samačkim kućanstvima kretao se od 44,4\% (Općina Župa dubrovačka) do 86,2\% u Općini Civljane.

Statistika dijeli kućanstva prema tipu na privatna i institucionalna. Privatna kućanstva mogu biti: a) obiteljska (jednoobiteljska ili višeobiteljska uz uvjet da postoji barem jedna, uža, obitelj, ali mogu imati i članove koji ne pripadaju obitelji) i b) neobiteljska (samačka ili višečlana). 


\section{ZAKLJUČAK}

Temeljni demografski proces pograničnog područja Hrvatske u suvremenomu međupopisnom razdoblju jest depopulacija. Ona se odvijala intenzivnije nego na razini čitave Hrvatske. Osim pograničnog pojasa u cjelini, bila je prisutna i u većini općina/gradova (108) te naselja (72,3\%). Iako je prirodni pad kao negativna sastavnica (odrednica) bio prisutan u 110 općina i gradova, a negativni migracijski saldo u 99, depopulacija se odvijala prvenstveno pod utjecajem mehaničkoga kretanja stanovništva, tj. emigracije (61 JLS), a u manjem broju slučajeva pod utjecajem prirodnog pada stanovništva (47 JLS-a). Takav odnos karakterizira pograničje kao emigracijsko područje u razmatranom razdoblju 2001. - 2011., jer je i na razini čitave Hrvatske u većini općina/gradova glavni uzrok smanjenja ukupnog broja stanovnika bio prirodni pad stanovništva.

Naseljska struktura pograničja govori da $\mathrm{u}$ tom pojasu prevladavaju mala naselja, koja su ujedno i najpogođenija intenzitetom depopulacije. Smanjenjem (gubitkom) stanovništva te prostornom raširenošću ističe se dio najužega pograničnog područja naselja koji obuhvaća kontinuirani pojas od čak 103 naselja, a proteže se duž 42 općine/grada i četiri županije te tri međudržavne granice.

Stupanj ostarjelosti čitavoga pograničnog područja nije toliko izražen kao u ostalom dijelu Hrvatske, ali je izražena slabija feminizacija starije dobi u odnosu na ostali dio Hrvatske i zemlju u cjelini. Sve jedinice lokalne samouprave (općine i gradovi) već su na početku razdoblja bile u procesu starenja, no on se i dalje produbljuje jer se udio starog stanovništva povećao u 86 JLS-a. Analiza je pokazala da se kod pograničja u cjelini, kao i kod većine općina/gradova, prvenstveno riječ o »starenju odozdo (smanjenje udjela mladih $0-19$ u ukupnom stanovništvu). Gotovo dvije trećine samačkih kućanstava pograničja čini stanovništvo starije životne dobi (60 i više), što je izrazitije od ostalog dijela Hrvatske. Daljnjom raščlambom toga kontingenta ustanovljeno je da su u najzastupljeniji oni iz donjeg dijela tzv. četvrte dobi, odnosno stanovništva u srednjoj staračkoj dobi.

Istraživanje je potvrdilo da je hrvatsko pograničje jedno od prioritetnih problemskih područja kojem je potrebno pristupati s posebnom pozornošću. Stoga ovakve analize trebaju pridonositi planiranju prostornog razvoja, u okviru čega u dugoročno planiranje populacijske politike valja uključiti pronatalitetne i imigracijske mjere te destimuliranje iseljavanja. Stabilizacija naseljenosti pograničja treba biti cilj i sredstvo ravnomjernijeg razvoja Hrvatske. 


\section{LITERATURA}

Bognar, H. I. i Bognar, A. (2010). Povijesni razvoj i političko-geografska obilježja granice i pograničja Republike Hrvatske s Republikom Slovenijom na Žumberku i Kupskočabranskoj dolini, Geoadria, 15 (1): 187-224, doi: https://doi.org/10.15291/geoadria.549

Crkvenčić, I., (1998). Some geographic features of a Croatian border region along the Croatian-Slovenian border (the Čabranka-Kupa valley), Acta Geographica Croatica, 33: 73-82.

Crkvenčić, I. (2001). Certain Socio-Geographic Characteristics of a Croatian-Slovenian Border Region (Along the Čabranka-Kupa Valley), Acta Geographica Croatica, 35: 97-110.

Crkvenčić, I. (2002). Žumberačka gora - Transformation from a Refuge to an Exodus Zone, Migracijske i etničke teme, 18 (4): 289-306.

Crkvenčić, I. (2004a). The Posavina border region of Croatia and Bosnia-Herzegovina: development up to 1918 (with special reference to changes in ethnic composition), Društvena istraživanja, 13 (1-2/69-70): 293-314.

Crkvenčić, I. (2004b). The Posavina border region of Croatia and Bosnia-Herzegovina: development from 1918-1991 (With Special Reference to Changes in Ethnic Composition), Društvena istraživanja, 13 (3/71): 579-595.

Crkvenčić, I. i Crkvenčić, M. (2003a). Prekodravlje-Repaš: development of the settlement and population, Društvena istraživanja, 12 (3-4): 445-468.

Crkvenčić, I. i Crkvenčić, M. (2003b). Prekodravlje-Repaš: razvoj naselja i stanovništva, Podravina, 2 (4): 133-149.

Horvat, U. (1993). Demografska analiza obmejnega območja slovensko-hrvaške meje v Severovzhodni Sloveniji, Dela, 10: 157-169, doi: https://doi.org/10.4312/dela.10.157169

Horvat, U. i Počkaj Horvat, D. (1994). Naravno in selitveno gibanje prebivalstva v Sloveniji $\mathrm{s}$ podrobno analizo $\mathrm{v}$ štirih občinah ob slovensko-hrvaški meji v Severovzhodni Sloveniji, Znanstvena revija, 6 (1): 19-36.

Josipovič, D. (2007). Žumberk: meja, etničnost, veroizpoved, rodnost in migracije prebivalstva - demogeografska analiza, Dve domovini, 25: 39-68.

Josipovič, D. i Kržišnik-Bukić, V. (2010). Slovensko-hrvaški obmejni prostor: etnične vzporednice med popisi prebivalstva po letu 1991. Ljubljana: Inštitut za narodnostna vprašanja.

Kržišnik-Bukić, V. (1995). O Slovencih v narodnostni sestavi prebivalstva po naseljih v obmejnih hrvaških občinah pred razpadom Jugoslavije, u: V. Kržišnik-Bukić (ur.). Slovenci v Hrvaški: zbornik skupine avtorjev. Ljubljana: Inštitut za narodnostna vprašanja, 229-259.

Kržišnik-Bukić, V. (1997a). Hrvati po narodnostni opredelitvi in po maternem jeziku $\mathrm{v}$ naseljih obmejnih slovenskih občin s Hrvaško pred razpadom Jugoslavije, $\mathrm{u}$ : $\mathrm{M}$. Domini (ur.). Hrvati u Sloveniji: zbornik radova, Znanstveni skup, Zagreb, 20 - 21. lipnja 1996. Zagreb: Institut za migracije i narodnosti, 175-205.

Kržišnik-Bukić, V. (1997b). Narodnostna sestava v obmejnem prostoru med Slovenijo in Hrvaško: Statistični kazalci narodnostnega (samo)opredeljevanja in maternega jezika po popisu prebivalstva iz leta 1991 s posebnim poudarkom na Slovencih in Hrvatih. Ljubljana: Inštitut za narodnostna vprašanja. 
Nejašmić, I. (2005). Demografski resursi pograničnih područja Hrvatske, u: Zimski seminar nastavnika geografije, 27.-28. siječnja 2005., Zagreb: sažeci predavanja. Zagreb: Hrvatsko geografsko društvo, 52-58.

Nejašmić, I. (2008). Stanovništvo Hrvatske: demogeografske studije i analize. Zagreb: Hrvatsko geografsko društvo.

Nejašmić, I. i Toskić, A. (2015). Starenje stanovništva pograničnih područja Republike Hrvatske, Acta Geographica Croatica, 40: 1-13.

Pokos, N. (1997). Kretanje stanovništva i etnički sastav prigraničnog pojasa Hrvatske i Slovenije, u: M. Domini (ur.). Hrvati u Sloveniji: zbornik radova, Znanstveni skup, Zagreb, 20 - 21. lipnja 1996. Zagreb: Institut za migracije i narodnosti, 163-174.

Pokos, N. i Mišetić, R. (2009). Temeljni demografski pokazatelji hrvatskoga pograničnog pojasa, u: T. Smerići G. Sabol (ur.). Sigurnost i obrana Republike Hrvatske u euroatlantskom kontekstu. Zagreb: Institut društvenih znanosti Ivo Pilar, 227-246.

Program prostornog uređenja Republike Hrvatske (ur. Salaj, M.), Ministarstvo prostornog uređenja, graditeljstva i stanovanja, Zavod za prostorno planiranje, Zagreb, 1999.

Repolusk, P. (1995). Elementi prebivalstvenega razvoja v obmejnih hrvaških občinah s poudarkom na Slovencih, u: V. Kržišnik-Bukić (ur.). Slovenci v Hrvaški: zbornik skupine avtorjev. Ljubljana: Inštitut za narodnostna vprašanja, 261-284.

Repolusk, P. (1999). Opredelitev obmejnega območja med Slovenijo in Hrvaško ter nekatere njegove geografske značilnosti, u: V. Kržišnik-Bukić (ur.). Slovensko - hrvaški obmejni prostor: Življenje ob meji: Predstavitev rezultatov terenske raziskave. Ljubljana: Inštitut za narodnostna vprašanja, 17-46.

Strategija prostornog uređenja Republike Hrvatske (ur. Salaj, M.), Ministarstvo prostornog uređenja, graditeljstva i stanovanja, Zavod za prostorno planiranje, Zagreb, 1997.

Zupanc, I. (2001a). Depopulacija sjeverne hrvatske Istre, Dela, 16: 179-191, doi: https:// doi.org/10.4312/dela.16.179-191

Zupanc, I. (2001b). Demografska kretanja sjeverne hrvatske Istre od 1857. do 1991. godine, Annales, 11 (2/26): 321-342.

\section{IZVORI}

Ispravak Zakona o potvrđivanju Sporazuma između Republike Hrvatske i Republike Slovenije o pograničnom prometu i suradnji, Narodne novine-Međunarodni ugovori, 20/97.

Objava o prestanku važenja Sporazuma između Republike Hrvatskei Bosnei Hercegovine o pograničnom prometu i suradnji, Narodne novine-Međunarodni ugovori, 5/13.

Objava o stupanju na snagu Sporazuma između Republike Hrvatskei Bosnei Hercegovine o pograničnom prometu i suradnji, Narodne novine-Međunarodni ugovori, 4/06.

Odluka Ustavnog suda Republike Hrvatske broj: U-I-3226/2006 od 9. srpnja 2008. Narodne novine, 95/08.

Popis gradova, općina $i$ županija s površinama, Državna geodetska uprava, Zagreb.

Popis stanovništva, kućanstava i stanova 2011. godine, Državni zavod za statistiku, Zagreb, www.dzs.hr

Popis stanovništva, kućanstava i stanova, 31. ožujka 2001., Državni zavod za statistiku, Zagreb, www.dzs.hr 
Sporazum između Republike Hrvatske i Bosne i Hercegovine o pograničnom prometu, http://www.mvep.hr/files/file/2013/130620-SOP1.pdf (7. 9. 2018.).

Statistički ljetopis Republike Hrvatske 2017., Državni zavod za statistiku, Zagreb, 2017.

Tablogrami rođeni i umrli po naseljima, Državni zavod za statistiku, Zagreb.

Zakon o dopunama Zakona o provođenju popisa stanovništva, domaćinstava, stanova i poljoprivrednih gospodarstava u 1991. godini, Narodne novine, 47/90.

Zakon o izmjenama i dopunama Zakona o brdsko-planinskim područjima, Narodne novine, 117/03.

Zakon o izmjeni i dopuni Zakona o područjima županija, gradova i općina u Republici Hrvatskoj, Narodne novine, 175/03.

Zakon o izmjeni i dopuni Zakona o popisu stanovništva, domaćinstava, stanova i poljoprivrednih gospodarstava u 1991. godini, Službeni list SFRJ, 72/90.

Zakon o područjima posebne državne skrbi, Narodne novine, 86/08.

Zakon o područjima županija, gradova i općina u Republici Hrvatskoj, Narodne novine, $86 / 06$.

Zakon o popisu stanovništva, domaćinstava, stanova i poljoprivrednih gospodarstava u 1991. godini, Službeni list SFRJ, 3/90.

Zakon o potvrđivanju Sporazuma između Republike Hrvatske i Bosne i Hercegovine o pograničnom prometu i suradnji, Narodne novine-Međunarodni ugovori, 3/05.

Zakon o potvrđivanju Sporazuma između Republike Hrvatske i Republike Slovenije o pograničnom prometu i suradnji, Narodne novine-Međunarodni ugovori, 15/97.

Zakon o provođenju popisa stanovništva, domaćinstava, stanova i poljoprivrednih gospodarstava u 1991. godini, Narodne novine, 16/90. 


\title{
Demogeographic Development of the Croatian Borderland $2001-2011$
}

\author{
Ivan Zupanc
}

SUMMARY

The paper deals with the population processes in the Croatian border area in the last period between the 2001 and 2011 censuses from a perspective of population geography. The emphasis is put on the two main processes - depopulation and population ageing. For this population geography analysis, borderland was defined on the basis of local self-government units (municipalities and towns). As a criterion, the immediate contact of each unit with the border was used. Based on such a criterion, 128 administrative units were extracted, with a total of 1877 settlements. Finally, the narrowest borderland was defined according to 599 settlements touching the outer state border.

The research was based on the results of the 2001 and 2011 censuses and on the data gathered from vital statistics (data on live births and deaths). In order to compare the data of the two censuses, the principle of the constancy of boundaries at the level of municipalities and towns was ensured, meaning that all boundary changes were harmonised. The main strategy was to use the same spatial coverage and constant boundaries between municipalities or towns (as units of local government) as well as between settlements. An estimate was made for two municipalities and twelve settlements.

The analysis was performed on three spatial levels: 1) the borderland as a whole, 2) 128 municipalities and cities, 3) 1877 settlements. In addition, the nearest part of the border area was defined by 599 settlements along the border. The Croatian border area extends to $15,538.8$ square kilometres making up $27.5 \%$ of the Croatian land territory, and in 2011 it was occupied by 685,913 inhabitants (16.0\% of the state).

The entire Croatian borderland was depopulated in the period observed with a loss of $7.1 \%$ of the inhabitants. Losses of population were higher than in the rest of Croatia $(2.7 \%)$ and in Croatia as a whole (3.4\%). The main component of population decline was net migration (in - out migration) which affected the depopulation with $62.2 \%$, while the second component was natural decrease with $37.8 \%$. In Croatia as a whole and in the part outside the borderland, both components impacted the population decline, but their ratio was different. The population of whole Croatia declined in the same period due to natural decrease with an impact of $62.3 \%$; while in the part of Croatia outside the border area the same component had an impact of $75.0 \%$.

Out of a total of 556 municipalities and towns of Croatia (according to the 2011 census), 128 units of local self-government $(23.0 \%)$ are in the border zone. There are 39 municipalities/towns sharing a border with the Republic of Slovenia, 26 with Hungary, 12 with the Republic of Serbia, 54 with Bosnia and Herzegovina and 1 with Montenegro. Depopulation was a fundamental demographic process in most municipalities/towns. During the period considered, 108 municipalities and towns $(84.4 \%)$ were affected. Component analysis suggests that natural decrease affected up to 110 units (18 units had a natural increase). At the same time, a negative net migration was achieved in 99 municipalities and towns (in 28 it was positive and in 1 it was zero). 
As with the borderland as a whole, the main cause of depopulation was emigration (negative net migration). Most of the municipalities/towns depopulated (86) shared a negative migration balance (a leading component in 49 units) and natural decrease (dominant in 37 units). In 12 units, total depopulation was caused exclusively by negative net migration (higher than natural increase), and in 10 units depopulation occurred as a result of natural decrease (the net migration was positive or zero). In municipalities and towns with population growth, the main generator was a positive net migration. Out of 6756 settlements of the Republic of Croatia in 2011, 1877 or $27.8 \%$ were in the border zone. As part of the legacy of the past, the settlement structure of the frontier is such that small settlements prevail. The category of settlements with up to 100 inhabitants covers as many as $50.2 \%$ of settlements $(39.3 \%$ of such settlements in whole Croatia). Among them, the most numerous is the category with 1-49 persons (34.8\% of all settlements), occupied by only $2.0 \%$ of borderland inhabitants. In the category including 50-100 inhabitants, there were $15.5 \%$ settlements while the one including 101-200 inhabitants there were $15.6 \%$. As many as $72.3 \%$ of settlements (1357) witnessed a reduced number of residents in 2001-2011, and 26 "died out" in the same period. The number of inhabitants increased in 403 settlements, 11 were repopulated (since in 2001 there had been no inhabitants), and in 45 settlements the number of inhabitants stagnated. There were 35 settlements in the two censuses (the so-called "dead villages"), so with 26 new ones, their number grew from 46 to 61 (40.7\% out of 150 non-resident settlements in the Republic of Croatia). In the example of the Croatian borderland, the rule has been confirmed that a settlement is less likely to become even smaller. In the five smallest categories, the index of change increased in line with the size of the category. Thus, while the smallest settlements (1-49) had a decrease of $-14.6 \%$, the decrease amounted to $-12.6 \%$ in the category of 50-100 inhabitants, $-11.9 \%$ in the one with 101-200 inhabitants, $-9.4 \%$ in the category including $201-500$ inhabitants and $-6.0 \%$ in the category with 501-1000 inhabitants.

In direct vicinity of the Croatian border, there are 559 settlements; 256 at the border with the Republic of Slovenia, 54 at the border with Hungary, 28 at the border with the Republic of Serbia, 218 at the border with Bosnia and Herzegovina and 7 at the border with Montenegro. Out of all units analysed, this area witnessed the most intense depopulation, amounting 8.6\% (from 339.594 people in 2001 to 306.983 in 2011). Of the 559 settlements in this area just below the border, 431 were depopulated $(77.1 \%), 3$ remained without population, 102 recorded an increase $(18.2 \%), 4$ were repopulated, 10 stagnated and 9 were without a resident in the two consecutive censuses (the so-called "dead villages"). In addition to the Croatian-Hungarian, Croatian-Serbian and Croatian-Bosnian-and-Herzegovinian border, the longest continuous depopulation zone extends to 103 settlements. The number of inhabitants in that area decreased by $13.0 \%$.

The ageing process was slower in the border area of Croatia, as the 2011 ageing index increased to 108.9 (by 20.3), while in the area outside the borderland it increased to 116.3 (by 25.1). At the same time, the index value for the whole Croatia increased by $24.3(90.7 \rightarrow 115.0)$. According to the second indicator (age coefficient), the share of elderly people in the total population increased in the border zone from $22.0 \%$ to $24.0 \%$ and in the rest of Croatia from $21.4 \%$ to $24.1 \%$. At the same time, the share of young people decreased from $24.8 \%$ to $22.0 \%$, and from $23.5 \%$ to $20.7 \%$, respectively. The ageing of population in the borderland is primarily a result of the decrease in the number and share of the young population (0-19). Their total number in ten years 
was relatively reduced by $17.5 \%$, while the number of elderly people increased by $1.5 \%$ at the same time. The process of young population decrease is slower in the rest of Croatia $(-14.3 \%)$, but on the other hand, the number of the old population increases considerably faster than in the borderland (+9.3\%).

What is also typical of the Croatian border area is a later feminisation of the old age. Here it begins from the 60-64 contingent, while in the rest of Croatia it is present in the age group of 40-44, and in Croatia as a whole from the age of 45-49.

At the beginning of the period analysed, according to the 2001 census, in 57 municipalities/towns the old population outnumbered the young, so that in only ten years their number increased to 87. Even in 115 municipalities and towns, the ageing index had increased by 2011, and in only 13 it had declined. The main cause of index increase at this level was also the depopulation of the young. Namely, in $76 \mathrm{mu}-$ nicipalities/towns, the index increased due to the simultaneous depopulation of the young and the old, with the number of young people decreasing at a higher rate than the old, while in 20 municipalities/towns the rate of decrease of the young population is higher than the rate of increase of the old population. The depopulation of the young contingent occurred in as many as 122 units (95.3\%), while the number of young people increased in only 6 municipalities/towns. At the same time, the age coefficient increased in 86 municipalities/towns, and decreased in 42 by reducing the age coefficient in all 13 units in which the ageing index decreased.

At the whole border area level, the share of single households increased by slightly less than a quarter $(2011=23.3 \%, 2001=20.8 \%)$, and their share in the total number of households is smaller than in Croatia in general (24.6\%) and in the part of Croatia which is not in the border zone (24.8\%). As the total number of single-person households increased by 4295 , it can be concluded that a growing number of persons live alone. According to the 2011 census, 53.826 inhabitants or $7.8 \%$ lived in a singleperson household. The structure of single-person households by sex suggests that they predominantly consist of elderly women (60.5\%). Although the share of singleperson households in the border area is somewhat smaller than in the rest of the state, nearly two-thirds (65.4\%) of single-person households comprise the older-age population (60 and more) which is much more than in the remaining part of Croatia outside the border area (58.9\%) or than the state average $(59.9 \%)$. If this contingent is broken down into five-year age groups, the most numerous are those aged 75-79 ( $22.5 \%$ of households aged $60+$ and $14.7 \%$ of all single-person households), followed by $70-74$ years $(21.3 \%$ and $13.9 \%)$.

The research has confirmed that the Croatian borderland is one of the priority problem areas to be approached with special attention. Therefore, such analyses should contribute to the planning of spatial development, within which the long-term policy of population planning should include pronatalist and immigration measures and discouragement of emigration. Stabilisation of settlements and population of the Croatian borderland should be the goal and means of a more balanced development of Croatia.

KEY WORDS: borderland, Croatia, population geography, population, depopulation, ageing 